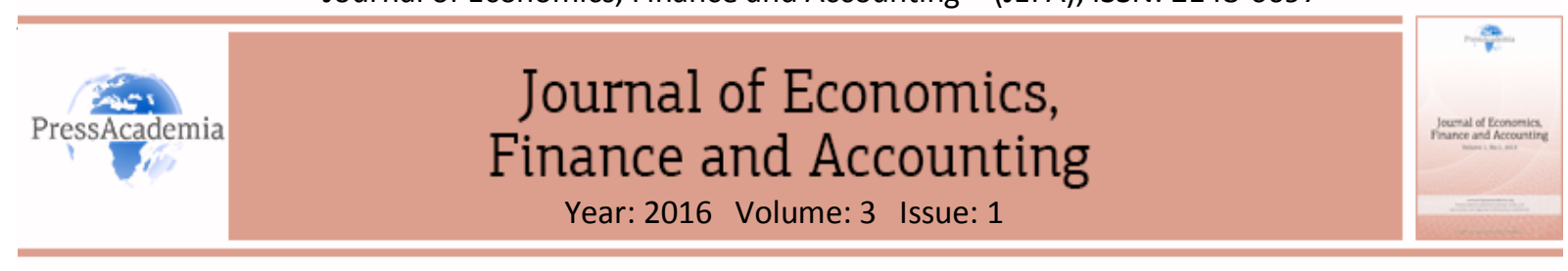

\title{
EFFECT OF INTERNAL CONTROL SYSTEMS ON FINANCIAL MANAGEMENT IN BARINGO COUNTY GOVERNMENT, KENYA
}

\author{
DOI: 10.17261/Pressacademia.2016116531
}

Cornelius Kipkemboi Lagat', Caroline Ayuma Okelo², Edwin Terer ${ }^{3}$

1,2,3 Kisii University. cornelius.lagat@yahoo.com, cayuma22@gmail.com

\begin{abstract}
This study intended to establish the effect of internal control systems on financial management in Baringo County government in Kenya. Internal control systems are integral components of the management processes of a public sector institution which should be established in order to provide reasonable assurance that the financial operations are carried out transparently and accountably. The study adopted the Committee of Sponsoring Organizations of the Tread way Commission (COSO) theoretical framework for analysis of internal control systems. According to COSO framework, the internal control system is analyzed using five variables namely; control environment, control activities, risk assessment, information and communication and monitoring. The research concluded that control activities and monitoring of information communication technology, significantly influences financial management as indicated by these analysis; $(F=5.836, p=000)$. Control activities $(\beta=.315, p=0.045)$ and ICS monitoring $(\beta=.432, p=0.049)$ significantly predict changes in financial management, while control environment $(\beta=.162, p=0.186)$ and information and communication $(\beta=.264, p=0.128)$ does not significantly predict changes in financial management. These research findings will be of significance to the Kenyan government in formulating policies related to efficient use of government resources. The findings will also be of significance to Baringo County in strengthening its internal control systems to enhance accountability and improve on financial management.
\end{abstract}

Keywords : Internal control system, control evironment, control actities, monitoring, information and communication. JEL Classification : G34, G38, G39

\section{INTRODUCTION}

It is important to note that internal controls just give reasonable, not total confirmation to an entity's management and board of directors that the organization goals will be accomplished. The probability of accomplishment is influenced by impediments inalienable in all frameworks of internal control (Hayes, 2005). All of government ministries and organizations ought to enhance the adequacy of internal control systems, internal audit function and organization commitment because they improve good governance (Eko and Hariyanto, 2011), moreover, such successful internal control framework can give information to management about the firms advancement, or absence of advancement toward the accomplishment of their destinations (Vijayakumar \& Nagaraja 2012).

In Kenya specifically Baringo county government has several internal control systems, only that they are week and poorly utilized. This therefore, formed the findings of the Auditor general (2014) as the use of technology was low, poor book-keeping and the county had not put in place systems to improve the situation. This clearly is an evident that the financial management in the county is not up to the expected standards locally and internationally, and this may create room for financial impropriety or unfair view of the financial reporting. The aspect of financial management is not captured in many researches and this forms the gap to be filled on the relationship between internal control systems and financial management in Baringo County government.

The United Nations Development Program me (UNDP) in 2005 completed a nation appraisal of corporate governance standards in Ghana, which prompted issuing of new corporate governance standards around the 
same time (Ghana County Report, 2005). This is related to this study whereby in Kenya we have integrated financial policies to enhance standards of operation and to be in line with international standards. Amid the 1980s, high-profile audit failures led to creation of the Committee of Sponsoring Organizations of the Tread way Commission (COSO), composed with the objectives of redefining internal control and the criteria for determining the effectiveness of an internal control systems (Simmons, 1997). They studied the causal factors that can lead to fraudulent financial reporting and developed recommendations for public companies, independent auditors, educational institutions, the Securities Exchange Commission (SEC), and other regulators (COSO, 1985).

Puttick (2001) states that internal controls as an arrangement of hierarchical strategies and sanction internal processes (internal controls) created by organizations to apparently accomplish management essential target of guaranteeing that the business works faultless. He further clarified that a business is said to be running easily in the event that they find themselves able to stick to the management policies, to secure the organization assets, set up a framework that would stop and eradicate manipulation of the accounting information.

According to Mercer University (2010) the United States of America and somewhere else in Europe have supported countries and corporate associations to place more emphasis on their internal control frameworks and internal auditing functions and risk management. In the United States for example in 1992, a gathering of organizations supported the development of the tread path commission to study and write about how to enhance the adequacy of internal control system, and in 2002 the US Congress passed the Sarbanes Oxley act giving new orders on how companies are to report on the effectiveness or otherwise of their internal control systems are to cover the viability or generally of their interior control frameworks (spring, 2005). For this study if Baringo county government adopts similar strategies of legislation, it will ensure its financial operations are done accountably and transparently.

Brink (2009) contents that; internal control concept has existed as early as there have been substantive relationships. He added, its origin can be documented and traced back to civilized communities that existed around 5000 B.C. The Governments of these empires imposed a number of taxes on individuals and business. For the proper accounting and collection of these taxes, an elaborate system of checks and counterchecks was established. Such early internal control systems were designed primarily to minimize errors, and safeguard state property from dishonest tax collectors. He continued that, the Mesopotamian civilizations, which existed about 3000 B.C., also utilized elaborate systems of internal controls. Summaries of the transactions were prepared by scribes who did not provide the original list of receipts and payments. Documents of that period contained ticks, dots, and check-marks indicating the existence of the auditing function during those times. This relates to our study when it comes to proper and up to date records that are kept in our financial institutions. Internal control controls have existed from old times. Michino (2011) reported that in Hellenistic Egypt there was a dual administration with one arrangement of administrators charged collecting taxes and another with supervising them. This can be comparable to Kenyan institutions whereby we have the Auditor who is independent responsible to give a fair view of the financial books of records in various organizations.

Internal control systems are integral component of the management processes of a public sector which for this study is to provide reasonable assurance that the financial management are carried out transparently and accountably. The County government was seen as the solution to the misuse of public financial resources at the national government hence there was need to bring resources closer to the citizens. The last two financial years that the county government has been in operation, has been characterized by allegation of misappropriation of financial resources as observed from the audit reports from the Auditor General, republic of Kenya (R.o.K, 2014). This therefore has led to frequent unrest by workers and public due to delayed payment of salaries, and misuse of funds by the office bearers respectively.

According to Mercer (2010) in USA Enron's and Pworldcom scandals that were revealed led to the bankruptcy of these corporations, this in effect culminated to the federal government of USA strengthening its internal control systems on financial performance through legislation. The senate passed the Sarbanes-Oxley Act of 2002. This law was able to set standards for all public company boards, management and public accounting firms on how financial information is to be reported by internal and external auditors on their financial performance. 
World Bank (2004) reported that Nigeria had not adopted the most recent international Financial Reporting Standards (IFRS) and thus operated weak accounting and auditing practices. The consequences were poor governance culture, financial fraud, insider abuse of management, poor asset and liability management, poor regulation, weak ICS and supervision. This crisis led to the adoption of financial reporting council of Nigeria Acts, 2011 by the senate. The primary objective of this was to ensure that companies comply, enforce and promote the standards when preparing their financial statements.

In Kenya according to the Auditor General report (2014) Baringo county specifically had the following loop holes in its systems; (i) weak financial control system, (ii) poor book keeping, (iii) no financial policies had been formulated, (iv) the use of technology was very low and the county government had not put in place systems to improve the situation (R.o.K, 2014). Baringo county government operates under Integrated Financial Management Information Systems (IFMIS), public finance laws and regulations, but with the findings of the Auditor General raises questions on internal control systems in place to safeguard misuse of financial resources. The purpose of the study was to determine the effect of internal control systems on financial management in Baringo County Government. The purpose of this study was to determine the effect of internal control systems on financial management in Baringo County government in Kenya.

\section{LITERATURE SURVEY}

In 1992, the Committee of Sponsoring Organizations of the Tread way Commission (COSO) issued Internal Control Integrated Framework to help businesses and other entities with their internal control systems (COSO, 1994). Nowadays the framework has been used as rule, regulation and policy, by thousands of companies around the world. COSO noticed a clear need for a robust framework to effectively manage risk. Therefore, in 2001 it initiated a project, along with PricewaterhouseCoopers, to develop an updated framework that would be readily usable by management.

In 2004 the framework was published and COSO believes that this updated framework Enterprise Risk Management - Integrated Framework fills the need. This framework expands on internal control and provides a broader focus on the whole subject of enterprise risk management (COSO, 2004). According to the framework, the objectives can be viewed in the context of four categories: strategic, operations, reporting and compliance: referring to high-level goals, which should be aligned with and supporting the company's mission.

As indicated by Hamed (2009) internal control systems entails proper and clear organizations of groups, in the premix of control variables brought in by management and the success of every business involved. Internal control system is all the systems and methods taken by the management so as to guarantee, guarantee to a great extent, as much successful cooperation as possible with the director of the company, the insurance of the capital, the prevention and the detection of fraud, as well as the early preparation of all the important financial information as indicated by Keitany (2000). Hongming and Yanan (2012) indicates that internal control system can be compared to the human sensory system which is spread all through the businesses bringing about requests and responses to and from the administration. It is specifically connected to the structural arrangement and the general standards of the business.

Control systems are very important because it works at all levels of every department. In measuring the viability or whether the internal control systems works depend on the following variables- Control Environment, Risk Assessment, Control Activities, Information and Communication, and Monitoring of ICS are present and functioning (Anduuru, 2005). Ahmad et al.,(2009). On the case of sufficiency the usage of a clear and direct channel of information assessment is realized that the unavailsablity of workers review is placed as a real case confronted by the inner moderators in leading and compellind in moderations.

The exploration results demonstrate noteworthy connections between years between reviews, internal control sufficiency, inside control adequacy and assessment of monetary execution checking on neighborhood government budgetary execution (Aikins, 2011). Feng et al., (2009) additionally did a study on internal control and administration direction; utilized survey found that internal control quality has a monetarily noteworthy impact on the exactness of administration direction. 
James (2005) showed that internal control helps in bringing surety that organized assignments leads to achieving the set objective as long as the aim is well understood especially in regard to the policy, prompts effectiveness in utilization of organization goods and eguipments whereby; occupations are done as clarified by their portrayal, accessibility of workers for work at all times, and fair portion of financial resources. Kayongo (2004) stated that for system to be effective there must be good usage of the corporate internal control systems. This controls and prevents financial errors and irregularities by detecting and checking them in time so as to prompting reliable accounting record (Faltering \& Tan, 2000).

Lawrence (2000) underscored that internal control is the heart of any organization and contended that a solid internal control capacity helps firms to work unequivocally and profitably. Kakuru (2001) expressed that conducting business includes various transaction that influence financial management of the firm. In the event that internal control is not all around actualized, it will adversely influence management and efficiency of the firm and consequently retard its ability. Internal controls helps directors to get the best measures of the effect of distinctive transactions adapted towards generating a diversified portfolio of investments, thus enhancing proper accountability.

As per Association of Chartered Certified Accountants ACCA (2004) assessment of risks includes the examination and foundation of arrangements in order to prevent the risks associated with the attainment of company objectives. The control activities include policies and procedure formulated by the management keeping in mind the end goal to effectiveness of carrying out activities with regard to the accomplishment of organizational goals.

The way to organizational survival, creating and maintaining wealth primarily lies on accountability built into governance structures of corporations According to Ice (2000) there is an in number relationship between accountability, and the objective of accountability is to enhance management and not to place accuse and punishment and hence, accountability enhances budgetary administration. Green (2003) alludes to accountability as an organizations' capacity to demonstrate, answer or explain its actions. It is considered accountability desirable because it increases the incentives for actors to perform as expected and that reliability can improve management and relationship among the parties. They argued that accountability increases the efficiency and effectiveness of an institutions and equally leading to increased legitimacy and credibility of government.

Internal control is a management work that is essential for fitting accountability and accountability for all funds and ought to be kept up at all times (Chen, 2004). Each organization is liable to a dangers depending upon several factors such as; the products and services it offers, the market in which it functions, the sources through which it is financed, and the way it utilizes its resources. Likewise, innovations in the financial sector have prompted expanded interest in increased demand for an effective risk management as well as sophisticated corporate governance. Consequently, the activities that are covered in the implementation of a good corporate internal control are overseeing activities in connection with authorizations and reconciliations, reviewing of employee performance, security of assets, and segregation of duties (Ishumgisa, 2001). In the current study internal controls systems such as; control environment, control activities, monitoring of internal control systems and information communication technology helps Baringo county government in ensuring that there is prudent financial management.

Saidu and Zabeda (2013) conducted study on impact of the effective internal control system on the internal audit effectiveness at local government level in Malaysia. They found that control environment, control activities, information communication and risk assessment influence audit effectiveness. In this study auditing helps to ensure proper financial policies and procedures are implemented in a way that will enhance financial management. A study by Goodwin-Stewart \& Kent (2006) using a sample of Australian listed companies, shows that the existence of an Internal Control System is positively associated with firm size and commitment to risk management. The risk and control awareness have an influence on the scope of the ICS. Sarens and De Beelde (2006) argued that when management is aware of risks and control activities, they are more likely to understand the role of the ICS in monitoring risk and control activities, thus it is more likely that they will support a relatively larger ICS. 38 active British businesses went into liquidation in the third quarter of 1992 and in 1991 a total of 21,827 businesses failed compared to 15,051 in 1990, majorly because of weak ICS 
(Richardson, Sonny \& Suzan, 1994).However in Uganda, about 90\% of Ugandan SMEs collapse within 3 years (Nyakundi et al.,2014). Lack of or weak ICSs are therefore an indicator of poor financial management especially if the control activities are not utilized maximumly.

Study by Ntongo (2012), on internal control, financial accountability and financial management in Health sector in Uganda, indicated that Internal controls have more influence than Financial accountability on the dependent variable $(r=0.572 * *, P<0.01)$ and $\left.r=0.549^{* *}, p<0.01\right)$ respectively. They concluded that effective financial management is likely to be achieved if internal controls are strengthened. This also implies that if ICS is implemented in Baringo county Government, it will improve on financial management.

Control environment sets the tone for organizations, affecting the consciousness of its people. The control environment mirrors the public service board and county executive committee commitment to internal control in the county. Components of the control environment include the organization structure of the institution, management's philosophy and operating style, the integrity, ethics, and competence of personnel, the external influences that effect the organization's operations and risk management practices, the attention and direction provided by the public service board and the committees and the effectiveness of human resources policies and procedures. Hevesi (2005) on the other hand, considers the Control environment to be the mentality toward internal control and control cognizance built up and kept up by the management and workers of an organization.

According to Rezae et al (2001), internal control activities occur through the organization. They include a range of activities such as; approvals, authorizations, verifications, reconciliations, reviews of operating performance, security of asset and segregation of duties. They incorporate an extensive variety of various exercises such as approvals, authorizations, verifications, reconciliations, performance reviews, maintenance of security, and the creation and maintenance of related records which provide evidence of execution of these activities as well as appropriate documentation (Steeves, 2004). Administrative and regulatory measures that are professional dynamic in nature and keep undesirable occasions from happening are what he alluded to as preventive controls. They composed of; proper authorization, segregation of duties, sufficient documentation, and physical control of assets.

Walker, Shenkir \& Burton (2003) contended that Information and communication systems or processes support the identification, capture, and exchange of information in a form and time frame that enables people to carry out their responsibilities. Chen (2004) showed that Information and communication systems give reports containing operational, financial and compliance related information that make it possible to run and control an organization. Wales (2005) accentuated that reliable and relevant information from both internal and external sources must be identified, captured, processed, and communicated to people who need it in a form and time frame that is useful.

Monitoring is the assessment of internal control performance over time; it is proficient by progressing checking exercises and by particular assessments of internal control, for example, self-assessments, peer reviews, and internal audits. The reason for monitoring is to figure out if internal control is adequately designed, properly executed, and effective. Internal control is adequately designed and properly executed if all five internal control components (Control Environment, Risk Assessment, Control Activities, Information and Communication, and Monitoring) are present and functioning as designed (Springer, 2004). Lary (2009) views monitoring as needed to ensure that planned administrative, operational and financial tasks and activities are carried out in a timely and proper manner such that set internal control objectives and organizational performance are achieved. Monitoring also aims at determining whether organizational members are carrying out or have carried out their tasks efficiently and effectively as required by the organizations' policies.

The purpose of the study was to establish effect of internal control systems on financial management in County Government of Baringo. The independent variables were; control environment, control activities, information and communication, and monitoring, while the dependent variable were the financial management as illustrated in Figure 1. 


\section{Fig. 1: Conceptual Framework}

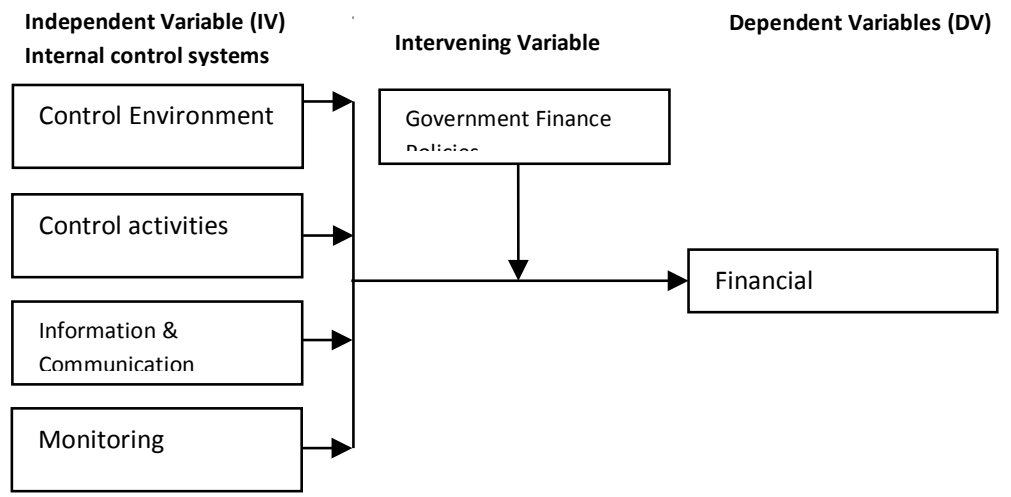

Control environment provides the tone set by the top management, its philosophy, style and supportive attitude towards internal control system, as well as the competence, ethical values, integrity and morale of the people of the organization. This will define the conducts of the employees, and hence influence financial management.

The control activities composed of activities undertaken by the middle level management such as approvals, authorizations, verifications, reconciliations, performance reviews, maintenance of security, and the creation and maintenance of related records which provide evidence of execution of these activities as well as appropriate documentation, the level of top management commitment to control environment activities influence financial management.

\section{DATA AND METHODOLOGY}

Kothari (2004) observes that a descriptive survey research design is used when one wants to get information on the current status of a person or object. The design has enabled the the acquisition of relevant information on the effect of internal control systems on financial management in Baringo County. The study was conducted in Baringo County Head quarters. The study targeted employees in financial and accounting positions at the County head quarters.

Sampling procedure refers to part of research plan that indicates how cases are to be selected for observation while sample size refers to number of items sampled from bigger population that their findings was used to generalize about the whole population (Kothari, 2004). Given the small number of employees in the finance department in Baringo County, census was used; hence the total 97 employees participated in the study.

Table 1: Sampling of Respondents

\begin{tabular}{lc}
\hline Departments & Population \\
\hline Internal Audit and Risk Services & 5 \\
Accounting and Reporting & 21 \\
Supply Chain Management & 9 \\
Budget and economic Planning & 11 \\
Administrative Services and Revenue Management & 51 \\
\hline Total & $\mathbf{9 7}$ \\
\hline
\end{tabular}

The study collected both primary and secondary data. The researcher used structured questionnaires to collect primary data. Borg et al., (1993) observes that questionnaires are used to obtain descriptive information from a larger sample. 
Data was collected using questionnaires because it allows the researcher to reach a large sample within a limited time. Borg et al., (1993) observes that questionnaires are used to obtain descriptive information from a larger sample. In the questionnaires, section A captures on demographic information, section B on control environment, section $C$ on control activities, section $D$ on information and communication, section $D$ on Monitoring of internal control and section E on Financial Management.

The researcher used both open ended and structured questionnaire, open ended questionnaires allow respondent to respond at their own pace in depth using their own words, structured questionnaire included use of Likert rating scale method as they are easy to complete and do not put off respondents. They also help the researcher to compare responses given to different items and hence minimize subjectivity and makes possible to use quantitative analysis (Mugenda and Mugenda, 2003).

Secondary data was obtained from County financial reports, county business magazines and any other available past published materials pertaining financial management in the county.

Validity is the degree to which a test measures what is suppose to measure, it is the accuracy and meaningfulness of inferences, which are based on research results (Orodho, 2009). Content validity was determined by making logical links between questions and the objectives of the study. The researcher made sure that the items in the instruments are well balanced so as to capture all what the study intents, that is should have similar and equal representation of the questions. After doing so, the researcher presented the instruments to three experts for scrutiny and advice.

Reliability is a measure of the degree to which a research instrument yields consistent results or data after repeated trials, thus giving it accuracy or precision (Sekaran, 2003). Pilot study was carried out in Elgeiyo Marakwet County. The pilot study ensured suitability and clarity of questions on the instruments designed, relevance of the information being sought and the language from responses given. In addition, a measure internal consistency using cronbach's alpha formula was determined as a test of reliability. The results for correlation co-efficiency for the pilot study above 0.83 indicating that the instruments are reliable. Fraenkel and Wallen (2003) contended that this method is the most convenient as it requires one administration and can be used to examine the correlation among all items measuring each variable.

Quantitative data was analyzed using descriptive statistical methods, frequencies and percentage with the aid of Statistical Package for Social Science version 20.0 (SPSS). According to (Mugenda and Mugenda, 2003) descriptive statistics features assist in variable response comparison and give a clear indication of response frequencies. Hypothesis was tested using regression model. Qualitative data from open ended questions was analyzed using content analysis. Regression analysis was conducted to establish the effect of the internal control systems on financial management and correlation to show the functional relationship between the predictor and the response.

The regression model adopted is indicated in equation 1;

$y=\alpha+\beta_{1} X_{1}+\beta_{2} X_{2}+\beta_{3} X_{3}+\beta_{4} X_{4}+\varepsilon$

Where:

$\mathrm{y}=$ Financial Management

$\boldsymbol{\alpha}=$ Constant Term

$\boldsymbol{\beta}_{\mathbf{1}}, \boldsymbol{\beta}_{2}, \boldsymbol{\beta}_{\mathbf{3}}, \boldsymbol{\beta}_{\mathbf{4}}=$ Beta Coefficients

$\mathrm{X}_{1}=$ Control environment

$\mathrm{X}_{2}=$ Control activities

$\mathrm{X}_{3}=$ Information and Communication

$\mathrm{X}_{4}=$ Monitoring

$\dot{\varepsilon}=$ Error Term 


\section{EMPIRICAL FINDINGS}

Majority of the respondents $62(66.0 \%)$ were males while $32(34.0 \%)$ were females, the findings indicates that the employees in Baringo County finance departments are fairly distributed and meet the constitutional gender requirements.

The information on the education level of the respondents indicated that most of the respondents $44(46.8 \%)$ had bachelors degree, 35(37.2\%) had diploma, 9(9.6\%) had masters degree while 6(6.4\%) had certificate, as illustrated in Figure. 2.

Fig 2: Respondents Level of Education

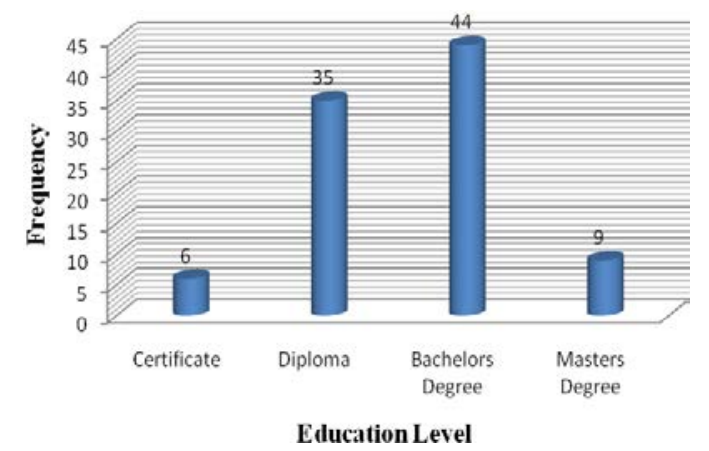

The respondents were well distributed with the majority 37 (39.3\%) aged between 30-39\%, 21(22.3\%) aged between 18-29, 20(21.3\%) aged above 50 years and 16(17.0\%) aged 40-49 as indicated in Figure 3.

\section{Fig. 3: Age of Respondents}

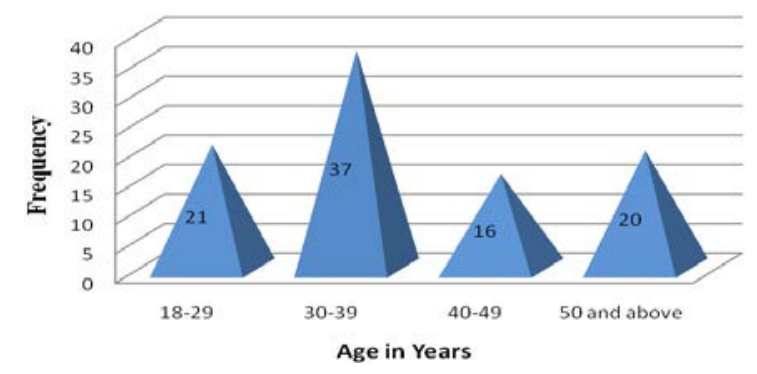

The first objective of the study was to establish effects of control environment on financial management in Baringo County. The findings indicated that there is a well elaborate organization structure in Baringo County that enhance internal control system, as indicated by 56 (59.6\%) of respondents that strongly agreed and 34 $(36.2 \%)$ that agreed. On statement that the policies and procedures are documented and well defined 77 $(81.9 \%)$ agreed. There are Systems that have been put in place to detect and correct errors, since 25 (26.6\%) strongly agreed and $26(27.7 \%)$ agreed. On the statement on the organizational culture, code of conduct, human resource policies and performance reward systems support the internal control systems, 11 (11.7\%) strongly agreed, 38 (40.4\%) agreed, and 22 (23.4\%) disagreed and 8 (8.5\%) strongly disagreed.

The study established that there is an elaborate scheme of motivating employees, as shown by $11(11.7 \%)$ of respondents strongly agreed and 39 (41.5\%) agreed. Most respondents 40 (42.6) agreed and 20 (21.3\%) strongly agreed that management philosophy is well stated. The respondents also agreed that the operation style is smooth and effective in the county, 16 (17.0\%) agreed and 50 (53.2\%). The study also established that employees are competent and skilled in the county, as indicated by 47 (69.1\%) respondents who agreed and $27(28.7 \%)$ strongly agreed. 
Correlation analysis was used to establish the relationship between control environment and financial management. The results indicated that there is a weak positive correlation between control environment and financial management $\left(r=.313^{* *}, p=002\right)$. This therefore implies that a good control environment lead to effective financial management in the county.

Table 2: Correlation between Control Environment and Financial Management

\begin{tabular}{|l|l|c|c|}
\hline & & Financial Management & Control \\
\hline \multirow{4}{*}{ Financial Management } & Pearson Correlation & 1 & $.313^{* *}$ \\
\cline { 2 - 4 } & Sig. (2-tailed) & & .002 \\
\cline { 2 - 4 } & $\mathrm{N}$ & 94 & 94 \\
\hline \multirow{4}{*}{ Control } & Pearson Correlation & $.313^{* *}$ & 1 \\
\cline { 2 - 4 } & Sig. (2-tailed) & .002 & 94 \\
\cline { 2 - 4 } & $\mathrm{N}$ & 94 & \\
\hline \multirow{2}{*}{$* *$. Correlation is significant at the 0.01 level (2-tailed). }
\end{tabular}

The second objective of the study was to determine the effect of control activities on financial management. The study established that policies and procedures exist to ensure critical decisions are made with appropriate approval, as shown by the response $62(66.0 \%)$ who strongly agreed and $27(28.7 \%)$ that agreed. There are elaborate mechanisms put in place in the County to address weaknesses of internal controls system, as indicated by $67(71.3 \%)$ of the respondents that agreed with the statements. It was also established that sensitive information are restricted to certain employees only, as indicated by $26(27.7 \%)$ respondents who strongly agreed and 38 (40.4\%) that agreed.

$14(14.9 \%)$ of the respondents strongly agreed and $47(50.0 \%)$ agreed that there is a system in place to ensure that employees are rotated periodically. Independent reconciliations of revenue collection is done on regular basis is done as shown by $24(25.5 \%)$ of the respondents who strongly agreed and $43(45.7 \%)$ that agreed. Majority of the respondents 68 (72.3\%) strongly agreed and 22 (23.4\%) agreed that proper authorization of transactions are done by the management.

$17(18.1 \%)$ of the respondents strongly agreed and majority $65(69.1 \%)$ of the respondents agreed that verification of the intended financial transactions are met by the county management. On statement that Performance of employees are reviewed from time to time, 27 (28.7\%) strongly agreed and 47 (50.0\%) agreed. Similarly, it was established that there is regular reconciliation of financial statements as indicated by 23 (24.5\%) respondents who strongly agreed and 44 (46.8\%) that agreed. The study established that there is proper documentation done to facilitate efficient operations of duties. The results as shown in Table 3, indicated a weak positive correlation $\left(r=.367^{* *}, p=0.000\right)$ between control activities and financial management. Indicating that, control activities significantly influence financial management.

Table 3: Correlation between Control Activities and Financial Management

\begin{tabular}{|l|l|c|c|}
\hline \multirow{4}{*}{ Financial Management } & & Financial Management & Control Activities \\
\hline & Pearson Correlation & 1 & $.367^{* *}$ \\
\cline { 2 - 4 } & Sig. (2-tailed) & & .000 \\
\cline { 2 - 4 } & $\mathrm{N}$ & 94 & 94 \\
\hline \multirow{4}{*}{ Control Activities } & Pearson Correlation & $.367^{* *}$ & 1 \\
\cline { 2 - 4 } & Sig. (2-tailed) & .000 & 94 \\
\cline { 2 - 4 } & $\mathrm{N}$ & 94 & \\
\hline \multirow{2}{*}{$* *$ Correlation is significant at the 0.01 level (2-tailed). } \\
\hline
\end{tabular}




\subsection{Effect of Adoption of Information Communication Technology (ICT) on Financial Management}

The third objectives of the study were to establish the effects of adoption of information communication technology (ICT) on financial management. The study established that there are established channels of communication for individuals to report suspected breaches of laws or regulation or other improprieties as indicated by $49(52.1 \%)$ of the respondents who strongly agreed and $37(39.4 \%)$ that agreed. Majority of the respondents $63(67.1 \%)$ agreed and $19(20.2 \%)$ strongly agreed that procedures have been put in place by the County for complains by the public and other agencies.

Most respondents $32(34.0 \%)$ agreed and $25(26.6 \%)$ strongly agreed that complains against staff are handled in professional manner. The response on whether the relevant authorities receive timely, relevant, and reliable reports for decision-making, 9 (9.6\%) strongly agreed and 49 (52.1\%) agreed. The study established that possible risks are communicated in a timely manner as shown by $37(39.4 \%)$ of the respondents who strongly agreed and $36(38.3 \%)$ that agreed. The study established that accurate financial reports are prepared in time, as indicated by $21(22.3 \%)$ of respondents who strongly agreed and $59(62.8 \%)$ that agreed. Similarly, there is maximum utilization of technology to run financial transactions, as shown by $29(30.9 \%)$ of the respondents who strongly agreed and $41(43.6 \%)$ that agreed. The statement on management is providing written description and reference manuals of duties and responsibility, most respondents $44(46.8 \%)$ agreed and 26 (27.7\%) strongly agreed. The study also established that $33(35.1 \%)$ strongly agreed and $36(38.3 \%)$ agreed.

There was no significant relationship between information and communication and financial management $(r=$ $.186, p=.072)$, since $p>0.05$, this indicates that there is no functional relationship existing between information, communication and financial management.

Table 4: Correlation of Information and Communication and Financial Management

\begin{tabular}{|l|l|c|c|}
\hline & & Financial Management & Information Communication \\
\hline \multirow{4}{*}{ Financial Management } & Pearson Correlation & 1 & .186 \\
\cline { 2 - 4 } & Sig. (2-tailed) & & .072 \\
\cline { 2 - 4 } & $\mathrm{N}$ & 94 & 94 \\
\hline \multirow{3}{*}{ Information and Communication } & Pearson Correlation & .186 & 1 \\
\cline { 2 - 4 } & Sig. (2-tailed) & .072 & 94 \\
\cline { 2 - 4 } & $\mathrm{N}$ & 94 & \multicolumn{2}{|c}{9} \\
\hline
\end{tabular}

\subsection{Effect of Monitoring of ICS on Financial Management}

The fourth objective of the study was to determine the effect of monitoring of ICS on financial management. The study established that the County assesses their internal control system from time to time as indicated by $51(54.3 \%)$ of the respondents who strongly agreed and $34(36.2 \%)$ that agreed. Majority of the respondents 63 (67\%) agreed that there are regular and periodic reviews of collection before the end of year report, it was also established that there are regular and periodic reviews of revenue collection before the end of year report, 32 (34.0\%) strongly agreed and $40(42.6 \%)$ agreed. Most of the respondents $36(38.3 \%)$ strongly agreed and 35 (37.2\%) agreed that the County has an independent monitoring unit.

The findings showed that there is appropriate communication to the executive on the effectiveness of the ongoing monitoring processes on risks and control matters as indicated by 50 (53.2\%) agreed and 16 (17.0\%) strongly agree. It also indicated that the county financial management is subjected to internal and external audit, as indicated by 43 (45.7\%) agreed and 24 (25.5\%) strongly agreed. Most respondents 45 (47.9\%) agreed, and $23(24.5 \%)$ strongly agreed that there is self assessment of workers in the county, and that internal audits are conducted regularly as shown by $39(41.5 \%)$ and $38(40.4 \%)$ of the respondents who strongly agreed and agreed respectively. 
The study established that the county management implements internal control recommendations made by internal and external auditors, as shown by the majority of the respondents $45(47.9 \%)$ agreed and $28(29.8 \%)$ strongly agreed. 33 (35.1\%) of the respondents strongly agree and 47 (50\%) agreed that administrative and financial tasks are carried out in a proper and timely manner. It was established that appropriate laws and regulations are followed in administering services as indicated by 24 (25.5\%) of the respondents who strongly agree and 44 (46.8\%) agreed.

\subsection{Relationship between ICS Monitoring and Financial Management}

The study established that there is a significant positive correlation $\left(r=.355^{* *}, p=000\right)$ between ICS monitoring and financial management at 0.01 level of significant(2-tailed) indicating a weak relationship of ICS on financial management.

Table 5: Correlation Analysis Monitoring of ICS and Financial Management

\begin{tabular}{|l|l|c|c|}
\hline \multirow{4}{*}{ Financial Management } & & Financial Management & Monitoring \\
\hline & Pearson Correlation & 1 & $.355^{* *}$ \\
\cline { 2 - 4 } & Sig. (2-tailed) & & .000 \\
\cline { 2 - 4 } & $\mathrm{N}$ & 94 & 94 \\
\hline \multirow{4}{*}{ Monitoring } & Pearson Correlation & $.355^{* *}$ & 1 \\
\cline { 2 - 4 } & Sig. (2-tailed) & .000 & 94 \\
\cline { 2 - 4 } & $\mathrm{N}$ & 94 & \\
\hline \multirow{2}{*}{$* *$. Correlation is significant at the 0.01 level (2-tailed). } & & \\
\hline
\end{tabular}

\subsection{Financial Management}

The study established that there is independent verification of financial statements and compliance with accounting principles in Baringo County as shown by 61 (64.9\%) of the respondents who agreed. The county government also safeguards the need to protect against threats to auditor's independence since 54 (57.4\%) strongly agreed and 31 (33.0\%) agreed. On the statement that the County government has frameworks of reporting to the central Government through its representatives i.e. the Senate, the line ministry, the auditor general etc, majority $63(67.0 \%)$ of the respondents agreed. It was also established that the County government has integrated within its reporting structures avenues where the individuals can report financial impropriety to the Governor, as indicated by $25(26.6 \%)$ and $43(45.7 \%)$ of the respondents that strongly agreed and disagreed respectively.

Majority of the respondents $47(50.0 \%)$ agreed and 18 (19.1\%) strongly agreed that the County use Forensic Accounting methodologies while carrying out audits. The county also employs the use of computer-based tools and techniques for detection and investigation of fraud, as indicated by $59(62.8 \%)$ of the respondents who agreed. Most of the respondents, 50 (53.2\%) agreed and 21 (22.3\%) strongly agreed that the County government audit policy promotes broader economic accountability in the management of public finance. The County has also instituted fraud control plans within its financial management to be in line with the Government of Kenya audit policy, since 52 (55.3\%) agreed and 28 (29.8\%) strongly agreed.

\subsection{Regression Analysis}

\section{(i) Model Summary}

The overall prediction of independent variables (control environment, control activities, information and communication and ICS monitoring) on the dependent variable (financial management) is 0.456 which is a positive and moderate correlation. The coefficient of determination is indicated by $\mathrm{R}$ square of 0.208 indicating that the predictors considered in the model can explain $20.8 \%$ of the changes in financial management. The study indicates that there are other factors that explain $79.2 \%$ of the change in financial management. 
Table 6: Model Summary

\begin{tabular}{|c|c|c|c|c|}
\hline Model & $\mathbf{R}$ & R Square & Adjusted R Square & Std. Error of the Estimate \\
\hline 1 & $.456^{\mathrm{a}}$ & .208 & .172 & .63608 \\
\hline
\end{tabular}

\section{(ii) Analysis of Variance}

Table 7 illustrates the overall significance of the predictors on financial management. The results indicate that at $5 \%$ level of significance, the overall prediction of variables under consideration; control environment, control activities, information and communication and ICS monitoring are significant. The results therefore indicate that there is a significant effect of internal control system on financial management in Baringo County.

Table 7: ANOVA ${ }^{b}$

\begin{tabular}{|l|l|c|c|c|c|c|}
\hline \multicolumn{2}{|l|}{ Model } & Sum of Squares & df & Mean Square & F & Sig. \\
\hline \multirow{3}{*}{1} & Regression & 9.444 & 4 & 2.361 & 5.836 & $.000^{\text {a }}$ \\
\cline { 2 - 7 } & Residual & 36.010 & 89 & .405 & & \\
\cline { 2 - 7 } & Total & 45.454 & 93 & & & \\
\hline
\end{tabular}

\section{(iii) Regression Coefficients of the Variables}

The regression co efficiency of the predictor variables are presented in Table 8 . The results indicate that Control activities $(\beta=.315, p=0.045)$ and ICS monitoring $(\beta=.432, p=0.049)$ significantly predict changes in financial management, while control environment $(\beta=.162, p=0.186)$ and information and communication $(\beta$ $=.264, p=0.128$ ) does not significantly predict changes in financial management. The t-test results indicates that control activities strongly predict financial management $(t=2.029, p=0.045)$ followed by monitoring of ICS $(\mathrm{t}=1.999,0.049)$

Table 8: Regression Coefficients

\begin{tabular}{|c|c|c|c|c|c|c|}
\hline \multirow{2}{*}{\multicolumn{2}{|c|}{ Model }} & \multicolumn{2}{|c|}{ Unstandardized Coefficients } & \multirow{2}{*}{$\begin{array}{c}\begin{array}{c}\text { Standardized } \\
\text { Coefficients }\end{array} \\
\text { Beta }\end{array}$} & \multirow[b]{2}{*}{$\mathbf{t}$} & \multirow[b]{2}{*}{ Sig. } \\
\hline & & B & Std. Error & & & \\
\hline \multirow[t]{5}{*}{1} & (Constant) & 1.135 & .585 & & 1.941 & .055 \\
\hline & Control Environment & .162 & .122 & .145 & 1.334 & .186 \\
\hline & Control activities & .315 & .155 & .232 & 2.029 & .043 \\
\hline & Information comm & .264 & .172 & .234 & 1.535 & .128 \\
\hline & Monitoring & .432 & .216 & .341 & 1.999 & .049 \\
\hline
\end{tabular}

The regression model used in the study was;

$y=\alpha+\beta 1 \times 1+\beta 2 \times 2+\beta 3 \times 3+\beta 4 \times 4+\varepsilon$

Regression results indicated that only two variables were significant; control activities and monitoring. Therefore placing these values into the formula for the significant variables;

$y=1.135+0.315 \times 1+0.432 \times 2+\dot{\varepsilon}$

\section{(iv) Hypothesis Testing}

The first hypothesis of the study $\left(\mathrm{H}_{\mathrm{o} 1}\right)$ was that there is no statistical significant relationship between Control environment and financial management in Baringo County Government. The regression result indicated $(t=$ 1.334, $p=0.186)$, the $p>0.05$, the null hypothesis was failed to be rejected. The second hypothesis $\left(H_{02}\right)$ was 
that there is no statistical significant relationship between Control activities and financial management in Baringo County Government. From the results $(t=2.029, p=0.043)$ which implies that control activities significantly affects financial management since $p<0.05$, therefore the null hypothesis was rejected.

The third hypothesis $\left(\mathrm{H}_{03}\right)$ of the study was that there is no statistical significant relationship between adoption of information communication technology (ICT) and financial management in Baringo County Government. From the results $(t=1.535, p=.128)$ indicating that information and communication does not significantly affect financial management since $p>0.05$, and hence null hypothesis was failed to be rejected. The fourth hypothesis $\left(\mathrm{H}_{04}\right)$ was that there is no statistical significant relationship between Monitoring of ICS and financial management in Baringo County Government. Since the findings ( $t=1.999, p=0.049) p<0.05$, the null hypothesis was rejected.

\section{SUMMARY OF FINDINGS}

\section{(i) Effects of Control Environment on Financial Management}

The findings indicated that there is a well elaborate organization structure in Baringo County that enhances internal control system, the policies and procedures are documented and well defined, there are Systems that have been put in place to detect and correct errors, and the organizational culture, code of conduct, human resource policies and performance reward systems support the internal control systems.

The study established also that there is an elaborate scheme of motivating employees; most respondents agreed that management philosophy is well stated. The respondents also agreed that the operation style is smooth and effective in the county, and that employees are competent and skilled in the county. Correlation analysis results indicated that there is a weak positive correlation between control environment and financial management $\left(r=.313^{* *}, p=002\right)$. This implies that in this study the county government should ensure that the control environment is good and effective so that financial management can be checked all the time.The results are in agreement with that of Mwachino, (2011) who revealed that there is a statistically significant positive relationship between the Control Environment and Revenue collection, $(r=0.482, \mathrm{P}<0.01)$ was found. This implies that KRA should establish a sound and clean Control Environment to increase its collection target. The top management and board of directors should ensure that the tone from above is good for all staff that implements development programs.

\section{(ii) Effect of Control Activities on Financial Management}

The study established that policies and procedures exist to ensure critical decisions are made with appropriate approval, there are elaborate mechanisms put in place in the County to address weaknesses of internal controls system, it was also established that sensitive information are restricted to certain employees only. Most of the respondents agreed that there is a system in place to ensure that employees are rotated periodically, independent reconciliations of revenue collection is done on regular basis is done, majority of the respondents agreed that proper authorization of transactions are done by the management.

Majority of the respondents agreed that verification of the intended financial transactions is met by the county management. Mawanda (2008) has suggested that segregation of approvals such that no one person should handle all aspects of a transaction from the beginning to the end. Performance of employees are reviewed from time to time, Similarly, it was established that there is regular reconciliation of financial statements, the study established that there is proper documentation done to facilitate efficient operations of duties.

The correlation results indicated a weak positive correlation $\left(r=.367^{* *}, p=0.000\right)$ between control activities and financial management. This indicates that active control environment will lead to effective financial management in Baringo county government. The results concur with Ntongo (2012) who found a significant positive relationship between controls activities and financial accountability $\left(r=0.478^{* *}, p<0.01\right)$ in the private health sector in Uganda.

\section{(iii) Effect of Adoption of Information Communication Technology (ICT) on Financial Management}

The study established that there are channels of communication for individuals to report suspected breaches of laws or regulation or other improprieties, majority of the respondents agreed that procedures have been put in 
place by the County for complains by the public and other agencies, most respondents agreed that complains against staff are handled in professional manner. The response on whether the relevant authorities receive timely, relevant, and reliable reports for decision-making, most respondents agreed. The study established that possible risks are communicated in a timely manner; accurate financial reports are prepared in time. Similarly, there is maximum utilization of technology to run financial transactions; the statement on management is providing written description and reference manuals of duties and responsibility. There was no statistical significant relationship between information and communication and financial management $(r=.186, p=.072)$. since $p>0.05$, meaning that the predictor information, communication has no functional relationship with financial management in Baringo county. The results concur with Mwachiro, (2011) he found that there is a direct correlation between Information and Communication and Revenue Collection in KRA $(r=0.317, P<0.01)$. This means that the more information is communicated in the right time and accurately the more the chance that KRA will collect more taxes.

\section{(iv) Effect of Monitoring of ICS on Financial Management}

The study established that the County assesses their internal control system from time to time, majority of the respondents agreed that there are regular and periodic reviews of collection before the end of year report. Most of the respondents agreed that the County has an independent monitoring unit, there is appropriate communication to the executive on the effectiveness of the ongoing monitoring processes on risks and control matters, and it also indicated that the county financial management is subjected to internal and external audit.

Most respondents agreed that there is self assessment of workers in the county, and that internal audits are conducted regularly. Reporting to the central Government through its representatives i.e. the Senate, the line ministry, the auditor general etc, majority of the respondents agreed. It was also established that the County government has integrated within its reporting structures avenues where the individuals can report financial impropriety to the Governor.

Majority of the respondents agreed that the County use Forensic Accounting methodologies while carrying out audits. The county also employs the use of computer-based tools and techniques for detection and investigation of fraud. Most of the respondents agreed that the County government audit policy promotes broader economic accountability in the management of public finance. The County has also instituted fraud control plans within its financial management to be in line with the Government of Kenya audit policy. The study established that there is a significant positive correlation $\left(r=.355^{* *}, p=000\right)$ between ICS monitoring and financial management at 0.01 level of significant (2-tailed) indicating a strong relationship of ICS on financial management.

The regression results indicated that internal control significantly influences financial management $(F=5.836, p$ $=000)$. Control activities $(\beta=.315, p=0.045)$ and ICS monitoring $(\beta=.432, p=0.049)$ significantly predict changes in financial management, while control environment $(\beta=.162, p=0.186)$ and information and communication ( $\beta=.264, p=0.128$ ) does not significantly predict changes in financial management. The study agree with (Muraleetharan, 2012) who established that control activities $(t=6.183, p=0.000)$ and ICS monitoring ( $t=5.342, p=0.000)$ were significant, while control environment $(t=-1.976, p$ 0.051) and information and communication ( $t=1.977, p=0.074)$. These results are is also in line with Gendion, Cooper \& Townley (2000) and Kakuru (2001) who argued that internal control enhances proper accountability.

\section{CONCLUSION}

The results indicate a weak positive relationship between control environment and financial management, but the regression analysis indicates that control environment does not significantly predict financial management. There was a weak positive relationship between control activities and financial management. Regression analysis indicated that, control activities significantly predict financial management.

There was a weak positive relationship between information and communication and financial management. Regression analysis indicated that, information and communication does not significantly predict financial management. There was a weak positive relationship between monitoring and financial management. Regression analysis indicated that ICS monitoring significantly predict changes in financial management. 


\section{REFERENCES}

Acca, (2005) ,Managing people: London foulks lynch.

Ahmad, N., Othman, R. \& Jusoff, K. (2009). The effectiveness of internal audit in Malaysian public sector. Journal of Modern Accounting and Auditing, 5(9), 784-790.

Anduuru, N.V. (2005). The accounting system and its related internal control system. Nairobi: Essential Management Consultancy Services Ltd.

Aikins, S. K. (2011). An examination of government internal audits' role in improving financial performance. Public Finance and Management, 11(4), 306-337.

Alan.G.H, (2005) standards for internal in New York state government,Comptroller handbook.

Aldridge, R. \& Colbert, J. (1994). Management's report on internal control, and the Accountant's response. Managerial Auditing Journal, 9(7), 21-28.

Amudo, A. \& Inanga, E. L. (2009). Evaluation of internal control systems: A case study from Uganda. International Research Journal of Finance and Economics, 27, $124-144$.

Brink, N. (2009). Theoretical Approach in an Internal Control System: A Conceptual framework and usability of Internal Audit. International Journal of Economic Sciences and Applied Research ,4 (1), 19-34.

Byekwaso, G. (2000). The effects of the communications process in the implementation of budgetary controls in the manufacturing companies in Uganda. Makerere University: Unpublished MBA Dissertation.

Borg, M.,Gall, J. and Gall, M. (1993). Applying Educational Research. White Plains, New York: Longman.

Chen, L. Y. (2004). Examining the effect of organizational culture and leadership behavior on. Organizational commitment and job satisfaction and job performance at small and middle-sized firms of Taiwan. The journal of American academy of business,5,432-438

COSO. (2004). Internal Control Integrated Framework of the American Institute of CPA.

COSO. (1998). Internal Control Integrated Framework Report of the committee of sponsoring organization of trade way commission, Jessey: American institute of CPA

COSO (1985) Definition of Internal Control on-line: http://www.coso.org.

DiNapoli, T. P. (1999). Standards of Internal control in New York State Government. www.d/NewYorkStateComptroller.htm.

Ejoh \& Ejom (2014). Impact of Internal Control Activities on Financial Performance of Tertiary Institutions in Nigeria. Journal of Economics and Sustainable Development, 5 (16),156-165

Eko, S. \& Hariyanto, E. (2011). Relationship between internal control, internal audit, and organization commitment with good governance: Indonesian Case. China-USA business review, ISSN 1537-1514 11(9),1237-1245

Feng, M., Li, C. \& McVay, S. (2009). Internal control and management guidance. Journal of Accounting and Economics, 48, 190-209

Fraenkel, J and Wallen, $\mathrm{N}$; (2003). How to design and evaluate research in education ( 5TH ED). New York: Mcgraw- Hill Higher Education.

Groth, M. (2005). Customers as good soldiers: Examining citizenship behaviors in internet service deliveries. Journal of management: 31, (7), pp 5 - 34 .

Green, F., L. (2003). Accountability: Putting Ethical Principles to work in your organization,ALERT, 17 (3), pp 1-15.

Hamed, A. (2009). A clear Look at Internal Control: Theory and Concept. Unpublished MBA Research Paper. University of Nairobi Hayes, R. (2005), Principles of Auditing. Pearson Education Ltd.

Ishumgisa, L., K. (2001). Antecedents of internal control in National Social Security Fund (NSSF). Makerere University: Unpublished MBA Dissertation.

James,S(2005) collaborative service delivery for public sector, HLB publications

Kang'ethe, P.M. (2002). ICT in Learning institutions. First Edition; Longman Publishers, Nairobi, Kenya.

Kayongo, P. (2004). Financial and Entrepreneurial among selected enterprises in Kampala District, MU, (Unpublished MBA Dissertation).

Kakuru, J. (2001). Basic Financial Management, MUBS, Kampala.

Keitany, J. L. (2000). The Internal Audit Control Function and its Implication for Risk Assessment by the External Auditor: A Case of Quoted Companies. Unpublished MBA Project Report, School of Business, University of Nairobi.

Kent, M. \& Williams, J. D. (1994), 'The use of audit committees for monitoring', Journal of Accounting and Public Policy,13(2),121-139 
Kothari C.R. (2004). Research Methodology (3nd Edition) Methods and Techniques, New Dheli: New Age International Publishers ISBN(13):978-81-224-2488-1

Mawanda, P. (2008). Effects of Internal Control System on Financial Performance in Institution of Higher Learning in Uganda: Uganda Martyrs University.M 102-20074

Michino, P. W. (2011). A Survey of the Impact of Internal Controls on Operational Efficiency among Non-Governmental Organizations in Nairobi. Unpublished Research Thesis. University of Nairobi.

Mugenda, G. \& Mugenda,O. (2003). Research Methods. Quantitative and qualitative approaches.2nd.Rev.ed Nairobi: Acts Press.

Mwakimasinde, M., Odhiambo, A and Byaruhanga, J (2014). Effects of internal control systems on Financial performance of Sugarcane Outgrowers Companies in Kenya. Journal of Business and Management, 16 (12), 62-73

Ntongo ,v. (2012).Internal controls, financial accountability and service delivery in private health providers of kampala district. Unpublished dissertation

Nyakundi,D.O.,Nyamita,M.O.\& Tinega.TM.(2014) Effect of internal control systems on financial performance of small and medium scale businesses enterprises in kisumu,Kenya,International, journal of social science and entrepreneurship,1(11),717-739.

Lame \& Tan. (2000). Women's Employment Decisions and Financial Arrangements within and the Ethics Procurements, IFA. New York. NY.

Lawrence, S. (2000). "The usefulness of ERP systems for effective management”. Industrial Management and Data Systems, $103(9), 34$ - 56.

Okwach, S. (2000). Revitalizing Financing of Higher education in Kenya: Resource utilization in public universities" Social sector Policy Review: Education No.1.

Orodho, J.A .(2009). Techniques of writing research reports: Nairobi, Mazola Publishers.

Puttick, V. E. (2008). The principles and practice of Audit: Business and Economics. Revised Edition. McGraw Hill High Education.

Rezaee, Z., Elam, R and Sharbatoghlie, A. (2001), Continuous Auditing: The Audit of

The Future, Managerial Auditing Journal, 16(3): 150-158.

R.o.K, (2014). Kenya National Auditor office report of the auditor general on financial operation of County government of Baringo. Financial year 2013/2014.

Saidu(2013). Impact of the effective internal control system on internal audit effectiveness at local government level in malaysia.unpublished thesis

Sarens. G, \& De Beelde (2006). Internal Auditors' Perception about Their Role in Risk Management. A comparison between US and Belgian Companies, Managerial Audit Journal , 21 (1), 2006. 63-80.

Sarens, G and De Beelde, I. (2006), “Internal Auditors' Perception about their Role in

Risk Management: A Comparison between US and Belgian Companies,

Managerial Auditing Journal, 21(1), 63-80.

Sekaran, J. (2003). Research Methods of Business. A skill Building Aproach. 4th ed.Heboken,NJ: John Wiley \&Sons. Singapore.

Simmons, M. R. (1997). COSO based auditing. Internal Auditor, December: 68-73.

Steeves, L. (2004). Centralization of control over Educational decision-making in Saskat chewan: An investigation of the centralization for control over educational decision - making in Saskatchewan school divisions. http//ww.ssta.sk.ca/order.htm.

Theofanis, K., Drogalas, G. \& Giovanis, N. (2011). Evaluation of the effectiveness of internal audit in Greek Hotel Business. International Journal of Economic Sciences and Applied Research, 4(1), 19-34.

Vijayakumar, A. N. \& Nagaraja, N. (2012). Internal control systems: Effectiveness of internal audit in risk management at public sector enterprises. BVIMR Management Edge, 5(1), 1-8.

Wang, R. Y. \& W. Y. Chung (2005). Redefining the Scope and Focus of Information Quality Work: Advances in Management Information Systems. M.E. Sharpe Inc, Armonk, New York.

Wales (2005). Export control organizational performance reporting.

Walker,P.L., Shenkir,W.G \&Barton,T.L (2003).ERMinpractice, internal auditor,60(4),51-55

Whittington, O. R; Panny, K. (2001). Principles of Auditing and other Assurance Services. Irwin / McGraw -Hill. New York. 